\title{
Analysis of Increasing the Three Pillars of Higher Education Development in Human Resources Behavior
}

\author{
Fathurrahman \\ Fakultas Keguruan dan Ilmu Pendidikan \\ Universitas Islam Lamongan, Indonesia \\ fath@unisla.ac.id
}

\author{
Abid Muhtarom \\ Fakultas Ekonomi \\ Universitas Islam Lamongan, Indonesia \\ abid@unisla.ac.id
}

\begin{abstract}
Improving the guidance of Higher Education Tridarma is the main factor that must be done by lecturers in all state and private universities. The research used in this study uses a quantitative descriptive approach. Using analysis software Eviews 9 and data in this study the results of questionnaires and interviews with respondents and observations of Islamic scholars in Lamongan. The subject of this study was 270 Islamic scholars at Lamongan University, East Java, Indonesia. The results of this study increase the guidance of Tridarma Perguran Tinggi by the behavior of human resources has run quite well, proven by 44 beginner lecturer research and community service 2017/2018 obtained from Ministry of Research, Technology, and Higher Education of Indonesia.
\end{abstract}

Keywords: teaching, research, community service, human resources behavior

\section{INTRODUCTION}

Tridharma Perguruan Tinggi (Three Pillars of Higher Education comprising Teaching, Research and Community Service) is an activity that must be carried out by all lecturers in Indonesia. The focus of tertiary education, both private and public, is a policy carried out by academics in academic terms, periodically proven by functional positions. The three main activities carried out are teaching where this activity is carried out in a room periodically and periodically, the second activity of research that can be required every year at least 2 and one semester 1 of research with scientific journal evidence (OJS).

Teaching in Higher education is an activity that does not need to be denied because it is a top priority to build quality and quality national life. In this activity lecturers and students are obliged to know and understand the importance of education. The more the lecturer understands the teaching function obtained, the recipient of knowledge (students) will get new information about the importance of education. On the one hand educational activities must be carried out by lecturers as educators whose function is to provide insights about their knowledge and on the other hand it is used by lecturers as evidence of functional positions according to Shee (2018); Filho (2018); and Matsuok (2018). To improve teaching in universities, research is needed.

Researching is a part of the task of the Tridarma University. In addition to teaching, the task of lecturers must also deepen their knowledge by making work to develop their knowledge. Career a lecturer must and must do research. The weight of lecturers' performance is around $25 \%-45 \%$, different from that of only $25 \%$ in lecturer performance. This means that the task of lecturers to conduct research must be increased. This can be done to increase the rank of rank. Lecturer of Lamongan Islamic University has done a lot of research, it can be proven through publication journals that each year requires 2 researches. As further proof that greater evidence in 2017/2018 there were 44 lecturers' researches that received a grant from Ministry of Research, Technology, and Higher Education of Indonesia. This further proves that the importance of research for continuing education in tertiary institutions according to Nulhaqim (2015); Yuliawat (2012); and Murdana (2018). Higher education has an autonomous right to manage its own institution as a center for organizing higher education, scientific research and community service. In line with that, the government demands and obliges lecturers to commit themselves to research conducted by Research \& Development research in the scope of Islamic University of Lamongan.

Community service is part of the Tridarma Higher Education besides teaching and research that cannot be separated from the other two darma. Support from the academic community is really needed inside ranging from lecturers, students, education staff and alumni. But outsiders are also urgently needed such as the government, sponsors and other collaborative partners. Through this activity Islamic University of Lamongan is in the midst of the community whose main purpose is useful for the nation and the State of Indonesia according to Yuliawat (2012) and developed by Shee (2018).

\section{METHOD}

Research methods this study uses a quantitative approach that utilizes data based on questionnaire results. The quantitative approach was chosen because this study aims to describe the Analysis of Improvement of Tridarma Higher Education Development in Behavioral Human Resources (Case Study Lecturer at Islamic University of Lamongan) while the questionnaire results presented in numerical form include averages and percentages aimed at supporting qualitative data.

Data collection techniques in this study used: (1) the questionnaire was used to obtain written answers from respondents about the Improvement Analysis of improving Tridarma University Development by Behavioral Human Resources (Case Study Lecturer at the Islamic University of Lamongan); (2) interviews are used to solicit data about the Improvement Analysis of improving Tridarma University Development by Behavioral Human Resources (Case Study Lecturer at the Islamic University of Lamongan); and (3) observations are used to collect data about the Analysis of Improvement Analysis of improving Tridarma University 
Development by Behavioral Human Resources (Case Study Lecturer at the Islamic University of Lamongan). While the data from the questionnaire were analyzed using descriptive statistical techniques assisted with eviews 9 application.

Furthermore, the researcher organized the data between one and the other in the form of a narrative text that was adjusted between the results of the study starting from the results of the questionnaire, interview and observation which then drawn a conclusion. The subjects of this study were 270 lecturers from the Lamongan Islamic University. From the function (1) can be modified into a linear model using logs according to Gujarati (2003) and Wandi (2018) are as follows:

$\mathrm{SDM}=\mathrm{x}_{0}+\mathrm{x}_{1} \log \mathrm{EDU}+\mathrm{x}_{2} \operatorname{LogRST}+\mathrm{x}_{3} \log \mathrm{SVR}+\varepsilon_{1}$

Note:

EDU $=$ Teaching

SRT $\quad=$ Research

SVR = Community Service
SDM = Human Resource

\section{RESULTS AND DISCUSSION}

\section{Discussion of Data Analysis}

The discussion of Analysis of Improvement of Tridarma University Development in Human Resources Behavior (Case Study Lecturer at the University of Lamongan Islamic University) The author uses the following analytical tools:

\section{Validity Test}

Validity test is used to measure the validity of a questionnaire. The existence of this test aims so that the data obtained can be proven scientifically. A questionnaire is said to be valid if the questions on the questionnaire are able to reveal something that will be measured by the questionnaire. How to measure the validity of calculating the correlation between the scores of each question with the total score (Ghozali, 2013). The results of testing in the validity test on the questionnaire data in the study can be seen in Table 1 .

Table 1

The Result of Validity Test

\begin{tabular}{|c|c|c|c|c|}
\hline No & Variable/Indicator & $\mathbf{r}_{\text {count }}$ & $\mathbf{r}_{\text {table }}$ & Information \\
\hline \multirow[t]{4}{*}{1} & \multicolumn{4}{|l|}{ Teaching (X1) } \\
\hline & Long time of devotion (X1.1) & 4,68131 & 1,9688 & Valid \\
\hline & Teaching method (X1.2) & 4,64217 & 1,9688 & Valid \\
\hline & Teaching system $(\mathrm{X} 1.3)$ & 4,65596 & 1,9688 & Valid \\
\hline \multirow[t]{4}{*}{2} & \multicolumn{4}{|l|}{ Research (X2) } \\
\hline & Number of journal publications (X2.1) & 2,67129 & 1,9688 & Valid \\
\hline & Research grant (X2.2) & 2,61687 & 1,9688 & Valid \\
\hline & Functional position (X2.3) & 2,67898 & 1,9688 & Valid \\
\hline \multirow[t]{3}{*}{3} & \multicolumn{4}{|l|}{ Community Service (X3) } \\
\hline & The amount of devotion (X3.1) & 4,70345 & 1,9688 & Valid \\
\hline & Long time of devotion \& Grant (X3.2) & 4,94231 & 1,9688 & Valid \\
\hline \multirow[t]{4}{*}{4} & \multicolumn{4}{|l|}{ Human Resource (Y) } \\
\hline & SINTA (Y.1) & 2,87215 & 1,9688 & Valid \\
\hline & Lecture (Y.2) & 2,91343 & 1,9688 & Valid \\
\hline & Google scholar (Y.3) & 2,92139 & 1,9688 & Valid \\
\hline
\end{tabular}

With $r_{\text {table }}$ at $\mathrm{df}=\mathrm{n}-5$ (270-4) and a probability of 0.05 obtained $r_{\text {table }}=1.9688$ shows that all indicators used to measure variables in this study have $r_{\text {count }}>r_{\text {table }}$, meaning that all indicators are said to be valid. It can be concluded that all data in independent and dependent research are declared true and can be continued for further research.

\section{Reliability Test}

Reliable test results in the first study can be seen in table 2 According to Ghozali (2013) Reliability is a tool to measure a questionnaire which is an indicator of the variable. A questionnaire is said to be reliable if a person's answer to a question is consistent or stable from time to time. The reliability test is carried out jointly on all statements taken from the results of qualitative data developed with a questionnaire and coded by giving an assessment with a Likert scale and the results of the assessment if the alpha value $>0.1381$ it is called reliable econometrics model for the alpha value model $>0.21424$.

Based on the table above it can be concluded that shows all Cronbach's Alpha values> 0.1381. This means that all variables in this study are declared reliable so that they are declared good for the study and can be extended to other analysis results.

Table 2

Reliability Test Result

\begin{tabular}{|l|c|}
\multicolumn{2}{c}{ Reliability Test Result } \\
\hline Rcount & 0,21424 \\
\hline Rtable & 0,1381 \\
\hline Reliability & Reliable \\
\hline
\end{tabular}

\section{Multiple Regression Analysis}

Multiple regression analysis is used to determine the effect of independent and dependent variables on the Analysis of Improvement of Tridarma University Development in Human Resource Behavior (Case Study of Lecturer at Lamongan Islamic University). In the multiple regression analysis using views version 9 the results obtained are as in Table 3 .

Based on Table 3, the results of the multiple regression above can form the equation of the multiple regression model as follows:

$\mathrm{Y}=\mathrm{a}+\mathrm{b}_{1} \mathrm{X}_{1}+\mathrm{b}_{2} \mathrm{X}_{2}+\mathrm{b}_{3} \mathrm{X}_{3}+\mathrm{e}$

$Y=19713.43+15351.98 X_{1}+19370.17 X_{2}+18177.21 X_{3}$

Based on the results of the multiple regression equation above, it can be explained as follows: (1) in the 
equation the constant value shows a positive value that is equal to 19713.43 which shows an appropriate relationship occurs, meaning that if all the independent variables are equal to 0, then HR (Human Resources) is 19723.43 ; (2) if the value of the teaching coefficient (X1) is positive, it means that the teaching variable (X1) has a positive influence on HR (Human resources) (X1) has a regression coefficient of 15351.98 and a positive sign is interpreted if the teaching variable rises by one unit it will increase HR (human resources) amounting to 15351.98 ; (3) if the research (X2) is positive, it means that the study has a positive influence on HR (Human resources) (Y) has a regression coefficient of 19370.17 and a positive sign is interpreted if the research variable is 19370.17 ; and (4) if community service (X3) is positive, it means community service (X3) is positive for HR (Human resources) (Y) has a regression coefficient value of 18177.21 and a positive sign is interpreted if the community service variable (X3) is 18177.21 .

Table 3

Multiple Regression Testing Results

\begin{tabular}{|l|c|c|c|c|}
\hline \multicolumn{1}{|c|}{ Variable } & Coefficient & $\begin{array}{c}\text { Std. } \\
\text { Error }\end{array}$ & t-Statistic & Prob. \\
\hline EDU & 15351.98 & 27147.28 & 4.808982 & 0.0000 \\
\hline SRT & 19370.17 & 2764.171 & 82.84133 & 0.0000 \\
\hline SVR & 18177.21 & 32173.14 & 4.759937 & 0.0000 \\
\hline C & 19713.43 & 24780.18 & 5.559165 & 0.0000 \\
\hline \multicolumn{5}{|l|}{} \\
\hline R-squared & 0.991111 & Mean dependent var & 96194.87 \\
\hline Adjusted R-squared & 0.933765 & S.D. dependent var & 105065.1 \\
\hline S.E. of regression & 27309.67 & Akaike info criterion & 13.13205 \\
\hline Sum squared residue & $2.17 E+10$ & Schwarz criterion & 13.30267 \\
\hline Log likelihood & -427.0750 & Hannan-Quinn criteria & 13.19327 \\
\hline F-statistic & 234.9368 & Durbin-Watson stat & 1.507619 \\
\hline Prob(F-statistic) & 0.000000 & & \\
\hline
\end{tabular}

Based on the results of multiple regression analysis that has a more dominant influence on the potential of the village is the visitor of the study (X2) because it has coefficients of 19370.17 . Thus, it can be interpreted that the hypothesis which states the research variable (X2) has a more dominant influence on HR (Human resources) (Y). Based on table 3 above obtained the results of regression calculations that can be seen the value of the coefficient of determination) obtained from the results of $\mathrm{R}$ square of 0.991111 .

Based on the research data that the Analysis of Improvement of Tri Darma Development of Higher Education by Behavior of Human Resources (Case Study of University Lecturer of Lamongan Islamic University), it can be explained that the improvement of Tridarma University by human resource behavior has been running quite well, as evidenced by 44 research of beginner lecturers and community service in 2017/2018 was obtained from Ministry of Research, Technology, and Higher Education of Indonesia. Researching is a part of the task of the tri university education. In addition to teaching, the task of lecturers must also deepen their knowledge by making work to develop their knowledge. In accordance with regulation from Ministry of Empowerment os State's Apparatus and Bureaucracy Reform of Indonesia Number 17 of 2013, as a career a lecturer must and must do research.

The weight of lecturers' performance is around
$25 \%-45 \%$, different from that of only $25 \%$ in lecturer performance. This means that the task of lecturers to conduct research must be increased. This can be done to increase the rank of rank. Lecturer of Lamongan Islamic University has done a lot of research, it can be proven through publication journals that each year requires 2 researches. As further proof that greater evidence in 2017/2018 there were 44 lecturers' researches that received a grant from Ministry of Research, Technology, and Higher Education of Indonesia. This further proves that the importance of research for continuing education in tertiary institutions according to Nulhaqim, Soni Akhmad, et al (2015); Yuliawat, Sri. (2012) and Murdana, Kadek Yudi. (2018). Higher education has an autonomous right to manage its own institution as a center for organizing higher education, scientific research and community service. In line with that, the government demands and obliges lecturers to commit themselves to research conducted by $\mathrm{R} \& \mathrm{D}$ research in the scope of Lamongan Islamic University.

\section{CONCLUSION}

Participating variables (X1), research (X2), and community service (X3) play a positive role in human resources $(\mathrm{Y})$. Research variable (X2) which is dominant towards increasing human resource development (Y). Cronbach's Alpha value $>0.1381$. Almost all variables in this study were declared reliable so that they were stated to be good for the study and could be extended to the results of other analyzes. Increasing the development of the Tridarma University by the protection of human resources has been going quite well, as evidenced by 44 novice lecturer studies and community service in 2017/2018 obtained from Ministry of Research, Technology, and Higher Education of Indonesia, increasingly proven to enhance an important role in research at the Islamic University of Lamongan.

\section{REFFERENCES}

[1] Abbas, W. 2018. Development of Agriculture Sector in Poverty Reduction in East Java (Study of Gks Plus Gerbang Kertasusila Plus Period 2010-2017). Retrieved 4 July 2019, from https://osf.io/preprints/inarxiv/4pa95/.

[2] Filho, W. L. 2018. The Role of Transformation in Learning and Education for Sustainability. Journal of Cleaner Production, 23(1), 1-9.

[3] Gujarati, D. 2003. Basic Econometrics. Jakarta: Salemba Empat.

[4] Matsuok, R. 2018. Concerted Cultivation Developed in a Standardized Education System. Accepted Manuscript. Social Science Research. DOI. 10.1016/j.ssresearch.2018.08.011.

[5] Murdana, K. Y. 2018. Pengaruh Pembinaan Keagamaan oleh Samanera dan Atthasilani terhadap Perilaku Keagamaan Umat Buddha di Malang Raya. Retrieved 4 July 2019, from http://inferensi.iainsalatiga.a c.id/index.php/inferensi/article/view/1369.

[6] Nulhaqim, S. A. 2015. Peranan Perguruan Tinggi dalam Meningkatkan Kualitas Pendidikan di Indonesia Untuk Menghadapi Asean Community 2015 Studi Kasus: Universitas Indonesia, Universitas Padjadjaran, Institut Teknologi Bandung. Share: Social Work Journal, 6(2), 17.

[7] Shee, N. K. 2018. Karen Education Department's 
Multilingual Education for Language Maintenance. Kasetsart Journal of Social Sciences. Journal homepage: http://www.elsevier.com/locate/ kjss.

[8] Yuliawat, S. 2012. Kajian Implementasi Tri Dharma
Perguruan Tinggi Sebagai Fenomena Pendidikan Tinggi di Indonesia. Retrieved 4 July 2019, from https://ejournal.jurwidyakop3.com/in dex.php/majalahilmiah/articl e/view/36/33 